\title{
ANALISIS PERHATIAN ORANG TUA SELAMA PEMBELAJARAN DARING TERHADAP KEMAMPUAN PEMAHAMAN MATEMATIS SISWA
}

\author{
Shofi Fatmala ${ }^{1}$, Henry Suryo Bintoro ${ }^{2}$, Sekar Dwi Ardianti ${ }^{3}$ \\ Mahasiswa Universitas Muria Kudus ${ }^{1}$, Dosen Universitas Muria Kudus ${ }^{2}$, \\ Dosen Universitas Muria Kudus ${ }^{3}$ \\ Jalan Lkr. Utara, Kayuapu Kulon, Gondanmanis, Bae, Kudus \\ Sur-el: shofi266@gmail.com¹, henry.suryo@umk.ac.id ${ }^{2}$, \\ sekar.dwi.ardianti@umk.ac.id ${ }^{3}$
}

Article info

Article history:

Received:11-02-2021

Revised :18-02-2021

Accepted:28-05-2021

Keywords:

Parents Attention,

Mathematical

Comprehention Skills

Kata Kunci:

Perhatian Orang Tua,

Kemampuan

Pemahaman

Matematis

\begin{abstract}
A B S T R A C T
This study aims to find out the form of parental attention given during online learning, factors that affect parents attention and the role of parents attention to students mathematical comprehention skills. This research uses data collection techniques in the form of observations, interviews, and documentation. Data analysis used in this research is qualitative descriptive data analysis. In this study, it was found that, 1) where most of parents pay attention to stundent, 2) The factors that affect the attention of parents are, (a) the presence of desire / need, (b) strong lack of stimulus, (c) busy activities / work, (d) physical condition, (e) mental and surrounding atmosphere, $(f)$ the educational ability of parents. 3) Students have sufficient mathematical comprehention skills. Parents attention is only one of the factors that affect students mathematical comprehention skills, another factor is the existence of internal factors and external factors.
\end{abstract}

Penelitian ini bertujuan untuk mengetahui bentuk perhatian orang tua yang diberikan selama pembelajaran daring, faktor-faktor yang memengaruhinya, serta peran perhatian orang tua terhadap kemampuan pemahaman matematis siswa. Teknik pengumpulan data diambil melalui observasi, wawancara, dan dokumentasi. Analisis data yang digunakan dalam penelitian ini adalah analisis data deskriptif kualitatif. Hasil peneitian menunjukkan bahwa, (1) sebagian besar orang tua memberikan perhatian kepada siswa. (2) Faktor-faktor yang mempengaruhi perhatian orang tua yakni, (a) adanya keinginan/kebutuhan, (b) kuat tidaknya stimulus, (c) kesibukan kegiatan/pekerjaan, (d) kondisi fisik, (e) suasana jiwa dan sekitar, (f) kemampuan pendidikan orang tua. (3) Siswa memiliki kemampuan pemahaman matematis yang cukup. Perhatian orang tua hanyalah salah satu faktor yang memengaruhi kemampuan pemahaman matematis siswa, faktor lainnya yaitu adanya faktor dari dalam diri siswa dan faktor dari luar. 


\section{JURNAL ILMIAH \\ BINA EDUKASI \\ ISSN 1979-8598 E-ISSN: 2655-8378 \\ http://journal.binadarma.ac.id/index.php/jurnalbinaedukasi \\ Vol. 14, No. 1, Juni 2021, 01 - 10}

\section{PENDAHULUAN}

Pendidikan adalah suatu usaha yang dilakukan oleh seseorang agar menjadi manusia yang berilmu dan berakhlak mulia. Pendidikan tidak hanya diperoleh dari bangku sekolah saja secara formal di dalam kelas, namun pendidikan juga bisa didapatkan secara informal melalui keluarga dan lingkungan. Keluarga merupakan tempat untuk anak mendapatkan pendidikan pertamanya. Bagian keluarga yang memiliki tanggung jawab dalam pendidikan anak ialah orang tua. Salah satu lembaga yang dipilih orang tua agar anak mendapatkan pendidikan dan untuk mewujudkan tujuan pendidikan nasional adalah sekolah. Pembelajaran di sekolah biasanya dilakukan secara langsung atau tatap muka antara pendidik dan siswa di dalam kelas.

Namun, pada akhir Bulan Desember tahun 2019, ditemukan virus corona yang berasal dari Wuhan, China. Dengan penyebaran yang begitu cepat dan tak terkendali, tak hanya China saja, virus tersebut telah menyebar ke berbagai negara, termasuk di Indonesia. Melihat situasi yang terjadi di Indonesia, yang semakin hari jumlah individu yang tertular virus corona semakin bertambah, pemerintah membuat beberapa kebijakan untuk mencegah meluasnya penyebaran coronavirus disease (COVID-19). Salah satu kebijakan yang dibuat oleh Menteri Pendidikan dan Kebudayaan Republik Indonesia yaitu untuk melaksanakan proses belajar dari rumah melalui pembelajaran daring atau pembelajaran jarak jauh. Menurut UU nomor 20 tahun 2003 tentang sisdiknas menjelaskan bahwa pendidikan jarak jauh ialah pelaksanaan pendidikan dimana siswa terpisah dengan guru dan kegiatan belajarnya memanfaatkan berbagai macam sumber belajar lain seperti teknologi informasi, komunikasi dan media lainnya. Daring merupakan singkatan dari dalam jaringan atau yang biasa disebut dengan online. Pembelajaran daring atau online juga biasa disebut dengan e-learning. Hamdani (2011) menjelaskan bahwa istilah E-learning yaitu $e$ singkatan dari electronic (elektronik) dan learning (belajar). Jadi e-learning ialah kegiatan belajar yang memanfaatkan bantuan media elektronik. Lebih jelasnya, e-learning ialah proses kegiatan belajar mengajar tanpa harus tatap muka antara guru dengan siswa. Dengan adanya alat elektronik yang terkoneksi internet, siswa dapat belajar di mana pun dan kapan pun tanpa harus datang ke kampus atau ke sekolah. Setiap sekolah memiliki kebijakan yang berbeda mengenai pelaksanaan pembelajaran daring, beberapa sekolah menggunakan aplikasi seperti Zoom, Google Classroom, dan WhatsApp untuk mendukung pelaksanaan pembelajaran daring. Menurut Silahuddin (2015) pembelajaran $e$ learning mempunyai beberapa keunggulan, antara lain: (1) dapat memberikan pengetahuan dan pengalaman yang menarik dan berarti untuk siswa karena keahliannya mampu berinteraksi langsung, (2) dapat membenahi tingkat pemahaman dan kemampuan mengingat seseorang terhadap ilmu yang disampaikan, (3) terdapat kerjasama dalam komunitas online, yang mempermudah jalannya proses perpindahan informasi dan komunikasi, (4) manajemen dan 


\section{JURNAL ILMIAH \\ BINA EDUKASI \\ ISSN 1979-8598 E-ISSN: 2655-8378 \\ http://journal.binadarma.ac.id/index.php/jurnalbinaedukasi \\ Vol. 14, No. 1, Juni 2021, 01 - 10}

pengelolaan yang terpusat, (5) memangkas biaya pendidikan, (6) menjadikan pusat perhatian dalam kegiatan belajar yang tertuju pada siswa. Selain kelebihan, Silahuddin (2015) menjelaskan bahwa terdapat beberapa kendala dalam pelaksanaan e-learning yaitu, (1) tidak seluruh orang mampu melaksanakannya dengan benar, (2) pembuatan programming yang lumayan lama untuk membuat $e$ learning yang interaktif dan sesuai yang diharapkan pengguna, (3) biaya cukup tinggi untuk infrastruktur e-learning yang baik, (4) tidak semua orang ingin memakai e-learning untuk perangkat belajar, (5) sumber daya manusia terbatas sehingga tidak semua orang mampu memanfaatkannya.

Sebagai upaya pemerintah dalam terselenggaranya pendidikan dan lebih mengoptimalkan implementasi kebijakan belajar dari rumah oleh Kementrian Pendidikan dan Kebudayaan untuk semua kalangan saat pandemik virus corona, Kementrian Pendidikan dan Kebudayaan bekerja sama dengan TVRI untuk membuat Program Belajar dari Rumah yang mulai tayang sejak 13 April 2020. Berdasarkan observasi, terdapat beberapa masalah antara lain, pembahasan pada program terlalu cepat sehingga siswa mengalami kesulitan dalam memahami materi, kesulitan dalam memahami materi akan berdampak pada kesulitan dalam memecahkan masalah pada soal.

Tanpa adanya pendampingan dari orang yang lebih paham dengan materi yang dipelajari, tentu akan menurunkan minat siswa untuk belajar dan siswa merasa sedikit kesulitan untuk memahami suatu materi, terutama dalam muatan pelajaran matematika. Fauzan, dkk (dalam Oktoviani, dkk 2019) menyatakan bahwa kemampuan pemahaman matematis ialah kemampuan siswa dalam mengetahui dan mengingat suatu konsep, prinsip, prosedur serta kemampuan memilih strategi penyelesaian pada suatu masalah yang ada. Dalam pelaksanaan pembelajaran daring tentu saja pemahaman siswa sangat penting, maka dari itu diperlukannya perhatian dari orang tua untuk mendampingi anak belajar. Suryabrata (2014) menjelaskan bahwa perhatian adalah memfokuskan tenaga psikis terhadap suatu objek tertentu dan banyak sedikitnya kesadaran yang mengiringi suatu kegiatan yang dilaksanakan. Sedangkan Nasution (dalam Martsiswati dan Suryono 2014) menjelaskan bahwa orang tua adalah orang yang di kehidupan sehari-hari disebut sebagai bapak dan ibu yang memiliki tanggung jawab terhadap keluarga dan rumah tangga, yaitu untuk memberikan pendidikan, mengasuh, dan menuntun anak-anaknya dalam menggapai suatu tahapan tertentu supaya anak siap untuk hidup bermasyarakat. Berdasarkan uraian di atas dapat disimpulkan bahwa perhatian orang tua adalah pemusatan tenaga psikis dan kesadaran oleh orang tua untuk memberikan tuntunan dan arahan yang ditujukan kepada anaknya. Bentuk perhatian yang diberikan bermacam-macam seperti yang dijelaskan oleh Koyimah (2016) yaitu: (1) Memberikan bimbingan, (2) Memberikan nasehat, (3) Memberikan motivasi dan reward, (4) Memenuhi kebutuhan belajar anak, (5) Pengawasan terhadap anak. 


\section{JURNAL ILMIAH \\ BINA EDUKASI \\ ISSN 1979-8598 E-ISSN: 2655-8378 \\ http://journal.binadarma.ac.id/index.php/jurnalbinaedukasi \\ Vol. 14, No. 1, Juni 2021, 01 - 10}

Tujuan penelitian ini adalah untuk mengetahui bentuk perhatian orang tua yang diberikan kepada anak selama pembelajaran daring, mengetahui faktor-faktor yang mempengaruhi perhatian orang tua kepada anak saat pembelajaran daring, mengetahui kemampuan pemahaman matematis siswa dengan dan tanpa adanya perhatian orang tua siswa.

\section{METODOLOGI PENELITIAN}

Penelitian ini menggunakan jenis penelitian deskriptif kualitatif. Sugiyono (2014) menelaskan bahwa metode penelitian kualitatif merupakan metode penelitian yang berdasarkan pada filsafat postpositivisme, yang dilaksanakan untuk mengkaji pada keadaan obyek alamiah, yang mana peneliti sebagai sumber instrumen kunci, pengambilan subjek sebagai sumber data dilakukan secara random, teknik pengumpulan data dengan trianggulasi (gabungan), analisis data yang bersifat induktif/kualitatif, dan hasil dalam penelitian kualitatif yang lebih menekankan makna daripada generalisasi. Setyosari (2012) menjelaskan pendekatan kualitatif deskriptif yaitu bertujuan untuk menggambarkan suatu kondisi, kejadian, objek apakah orang, atau segala sesuatu yang terkait dengan penelitian.

Penelitian ini dilaksanakan di masing-masing rumah siswa kelas $\mathrm{V}$ yang berasal tiga sekolah dasar yaitu SD 1 Pasuruhan Lor, SD 2 Pasuruhan Lor, dan SD 4 Ploso yang berada di Desa Pasuruhan Lor dan Ploso, Kabupaten Kudus, Jawa Tengah. Pengumpulan data yang digunakan yaitu melakukan wawancara mendalam secara langsung dengan guru kelas V SD 1 Pasuruhan Lor, guru kelas V SD 2 Pasuruhan Lor, guru kelas V SD 4 Ploso, kesembilan siswa dari ketiga sekolah dasar tersebut, beserta orang tua siswa, selanjutnya melakukan observasi pada saat proses belajar siswa dari rumah dan melakukan analisis dokumentasi berupa hasil pekerjaan siswa untuk memperkuat data. Tahap-tahap analisis data dalam penelitian ini menurut Sugiyono (2014) antara lain, data reduction, data display, conclusion drawing/verivication.

\section{HASIL DAN PEMBAHASAN}

\subsection{Bentuk Perhatian Orang Tua yang Diberikan kepada Anak selama Pembelajaran Daring}

Keluarga merupakan lingkungan pendidikan yang pertama dan utama bagi anak. Keluarga menjadi salah satu faktor yang dapat mempengaruhi hasil belajar siswa, terutama orang tua. Tugas orang tua tidaklah hanya memenuhi kebutuhan makanan, pakaian dan perlindungan saja. Orang tua sangat berperan penting dalam menentukan masa depan anak dengan cara memberikan perhatian yang cukup terhadap anak dalam hal pendidikannya. Perhatian orang tua merupakan pemusatan tenaga psikis dan kesadaran oleh orang tua yang ditujukan kepada anaknya. Pemberian 


\section{JURNAL ILMIAH \\ BINA EDUKASI \\ ISSN 1979-8598 E-ISSN: 2655-8378 \\ http://journal.binadarma.ac.id/index.php/jurnalbinaedukasi \\ Vol. 14, No. 1, Juni 2021, 01 - 10}

perhatian orang tua kepada anak dalam hal belajarnya tentu saja akan memberikan dampak yang positif bagi belajarnya anak, terutama dalam kemampuan pemahaman matematis siswa. Perhatian orang tua yang yang harus diberikan kepada anak menurut Koyimah (2016) antara lain, (1) pemberian bimbingan, (2) memberikan nasehat, (3) memberikan motivasi dan penghargaan, (4) memenuhi kebutuhan anak, (5) pengawasan terhadap anak.

Hasil penelitian melalui wawancara dan observasi menyatakan bahwa dari kesembilan subjek, terdapat enam orang tua yang memberikan perhatian yang tinggi kepada anak dalam hal belajarnya, karena keenam orang tua tersebut sebagian besar sudah menjalankan kelima bentuk perhatian orang tua dengan baik. Sedangkan tiga orang tua lainnya masih kurang dalam memberikan perhatiannya kepada siswa, terutama dalam bentuk perhatian memberi bimbingan dan pengawasan kepada siswa saat belajar. Terdapat beberapa alasan yang menjadikan orang tua tidak memberikan perhatiannya secara maksimal kepada anak antara lain kesibukan orang tua yang bekerja dan urusan pekerjaan rumah tangga, keterbatasan kemampuan dalam hal pendidikan, dan anak yang sudah memiliki kesadaran untuk belajar sendiri secara mandiri. Seluruh orang tua mampu memenuhi kebutuhan anak dalam hal menyediakan kebutuhan untuk menunjang kenyamanan anak dalam belajar, memberikan nasihat, memberikan motivasi dan penghargaan saat mencapai suatu keberhasilan serta menasihati untuk belajar, namun hanya setengah dari orang tua yang mampu menyediakan waktunya secara maksimal untuk memberikan pengawasan dan memberi bimbingan kepada siswa, padahal kedua hal tersebut juga merupakan faktor yang dapat memengaruhi belajar siswa dan sangat diperlukan untuk membangun pengetahuan yang ada pada diri anak serta mampu menyelesaikan berbagai permasalahan yang dihadapi oleh anak.

Orang tua sangatlah berperan penting bagi pendidikan siswa pada saat pembelajaran daring saat ini. Adanya perhatian dari orang tua terhadap siswa dalam hal belajar, siswa juga termotivasi untuk belajar dengan sungguh-sungguh, sehingga hasil yang diperoleh dari kegiatan belajar juga maksimal. Hal ini senada dengan hasil penelitian dari Safitri (2018) yang menjelaskan bahwa perhatian orang tua sangat berpengaruh pada psikologis siswa saat belajar, dapat memberikan dampak positif pada siswa, meningkatkan motivasi dan semangat siswa sehingga siswa akan terpacu untuk melakukan suatu kegiatan yang positif dan mampu menyelesaikan segala permasalahannya dalam belajar.

\subsection{Faktor-Faktor yang Memengaruhi Perhatian Orang Tua kepada Anak saat Pembelajaran Daring}

Dalam memberi perhatian kepada anak, tentu saja bukan suatu hal yang mudah bagi orang tua. Terdapat beberapa hal atau faktor yang dapat memengaruhi pemberian perhatian orang tua kepada anak dalam hal belajarnya pada hasil penelitian menyatakan bahwa faktor yang memengaruhi pemberian perhatian orang tua sebagai berikut.

(1) adanya keinginan/kebutuhan dari orang tua yang diharapkan dapat dicapai oleh anaknya; 


\section{JURNAL ILMIAH \\ BINA EDUKASI \\ ISSN 1979-8598 E-ISSN: 2655-8378 \\ http://journal.binadarma.ac.id/index.php/jurnalbinaedukasi \\ Vol. 14, No. 1, Juni 2021, 01 - 10}

(2) kesibukan kegiatan seperti bekerja dan pekerjaan rumah tangga;

(3) kuat tidaknya anak dalam menarik perhatian orang tua;

(4) suasana sekitar dan suasana jiwa dari orang tua;

(5) kondisi fisik orang tua; dan

(6) kemampuan pendidikan yang dimiliki oleh orang tua.

Faktor yang memengaruhi perhatian dari orang tua dalam penelitian ini sejalan dengan apa yang dijelaskan oleh Satiadarma (2001) bahwa perhatian seseorang dipengaruhi oleh beberapa faktor, sebagai berikut.

1. kuatnya stimulus;

2. ketertarikan seseorang akan sesuatu; dan

3. kapasitas seseorang.

Berdasarkan penjelasan di atas, didapatkan kesimpulan bahwa faktor-faktor yang memengaruhi perhatian orang tua pada anak yaitu (1) adanya keinginan/kebutuhan, (2) kuat tidaknya stimulus, (3) kesibukan kegiatan/pekerjaan, (4) kondisi fisik, (5) suasana jiwa dan sekitar, dan (6) kemampuan pendidikan orang tua.

\subsection{Peran Perhatian Orang Tua terhadap Kemampuan Pemahaman Matematis Siswa selama Pembelajaran Daring}

Matematika memiliki beberapa kemampuan yang harus dikuasai oleh siswa, salah satunya adalah kemampuan pemahaman matematis siswa. Kemampuan pemahaman matematis merupakan landasan penting dalam memecahkan masalah matematika atau masalah sehari-hari. Menurut Driver (dalam Alan dan Afriansyah, 2017) pemahaman adalah kemampuan untuk menjelaskan suatu situasi atau titidakan. Seseorang dikatakan paham, apabila ia dapat menjelaskan atau menggunakan konsep dari materi yang didapatkan secara mandiri. Pemahaman matematis sendiri merupakan kemampuan yang berhubungan dengan mengerti dan menguasai konsep-konsep matematika yang menyeluruh dan fungsional (Safitri, dkk., 2018). Jadi kemampuan pemahaman matematis adalah kemampuan untuk menjelaskan dan menerapkan konsep pada suatu permasalahan secara mandiri. Dalam penelitian ini indikator kemampuan pemahaman matematis yang digunakan sebagai berikut.

1. mampu menyatakan ulang konsep yang telah dipelajari;

2. mngidentifikasi dan membuat contoh dan bukan contoh;

3. menggunakan dan memanfaatkan serta memilih prosedur atau operasi tertentu; dan

4. mampu mengaplikasikan konsep atau algoritma terhadap penyelesaian masalah.

Penelitian ini dilaksanakan dengan cara penulis meminta dokumentasi berupa hasil pekerjaan siswa yang berhubungan dengan kemampuan pemahaman matematis siswa pada masing-masing sekolah dasar. Setelah mendapatkan hasil pekerjaan siswa tersebut, penulis melakukan analisis mengenai bagaimana kemampuan pemahaman matematis siswa jika dikaitkan dengan perhatian 


\section{JURNAL ILMIAH}

BINA EDUKASI

ISSN 1979-8598 E-ISSN: 2655-8378

http://journal.binadarma.ac.id/index.php/jurnalbinaedukasi

Vol. 14, No. 1, Juni 2021, 01 - 10

orang tua. Kesembilan siswa ini dipilih oleh guru kelas $\mathrm{V}$ berdasarkan kemampuan pemahaman matematis siswa. pada ketiga sekolah dasar tersebut memiliki KKM 65 pada muatan pelajaran Matematika, jika siswa mendapatkan nilai $\geq 65$ maka siswa dinyatakan tuntas, jika siswa mendapatkan nilai $<65$ maka siswa dinyatakan tidak tuntas.

Tabel 1. Perolehan Nilai Tes

\begin{tabular}{cccc}
\hline Nama & KKM & Nilai & Keterangan \\
\hline AZP & 65 & 77,5 & Tuntas \\
\hline MADP & 65 & 50 & Tidak tuntas \\
\hline ZR & 65 & 35 & Tidak tuntas \\
\hline AKP & 65 & 80 & Tuntas \\
\hline RKM & 65 & 87,5 & Tuntas \\
\hline ZPA & 65 & 50 & Tidak tuntas \\
\hline AANI & 65 & 80 & Tuntas \\
\hline AANA & 65 & 72,5 & Tuntas \\
\hline AAP & 65 & 57,5 & Tidak tuntas \\
\hline
\end{tabular}

Berdasarkan Tabel 1 perolehan nilai tes kesembilan subjek penelitian, terdapat lima siswa yang tuntas diantaranya, AZP, AKP, RKM, AANI, dan AANA. Sedangkan empat siswa lainnya yang tidak tuntas dalam tes yaitu, MADP, ZR, ZPA, dan AAP. Dengan analisis yang dilakukan pada dokumentasi berupa hasil tes siswa maka dapat disimpulkan bahwa siswa memiliki kemampuan pemahaman matematis yang cukup baik dalam menyatakan ulang konsep yang telah dipelajari, mengidentifikasi dan membuat contoh dan bukan contoh, menggunakan dan memanfaatkan serta memilih prosedur atau operasi tertentu, mampu mengaplikasikan konsep atau algoritma terhadap penyelesaian masalah.

Walaupun dalam tes mendapatkan rata-rata yang baik dalam namun terdapat beberapa siswa yang kurang dalam kemampuan pemahaman matematisnya. Hal tersebut dapat dipengaruhi oleh beberapa hal, salah satunya yaitu perhatian dari orang tua. Dari hasil analisis dalam penelitian ini juga mendapatkan hasil bahwa enam dari sembilan subjek penelitian mendapatkan perhatian yang tinggi dari orang tuanya, karena memberikan kelima bentuk perhatian secara baik, namun hanya empat siswa yang mampu memahami dan menyelesaikan persoalan dalam soal dengan baik, sedangkan dua lainnya masih belum mampu dalam memahami dan menyelesaikan permasalahan dalam soal dengan baik dan ketiga subjek penelitian lainnya merupakan siswa yang kurang dalam mendapatkan perhatian orang tua, karena belum semua orang tua memberikan kelima bentuk perhatian kepada siswa, hanya satu siswa saja yang mampu memahami dan menyelesaikan 


\section{JURNAL ILMIAH \\ BINA EDUKASI \\ ISSN 1979-8598 E-ISSN: 2655-8378 \\ http://journal.binadarma.ac.id/index.php/jurnalbinaedukasi \\ Vol. 14, No. 1, Juni 2021, 01 - 10}

permasalahan dalam soal dengan baik, sedangkan dua lainnya belum mampu memahami dan menyelesaikan permasalahan dalam soal dengan baik dan benar. Dalam hasil penelitian di atas, dapat disimpulkan bahwa perhatian yang diberikan orang tua kepada anak dalam hal belajar tidak sepenuhnya mempengaruhi hasil belajar siswa terutama kemampuan pemahaman matematis siswa. Terdapat faktor-faktor lain yang dapat memengaruhi kemampuan pemahaman matematis siswa, yaitu faktor dari siswa itu sendiri dan faktor dari luar. Faktor dari dalam siswa antara lain, (1) tingkat kecerdasan yang dimiliki siswa, (2) minat dan motivasi siswa untuk belajar matematika, (3) konsentrasi siswa saat belajar. Sedangkan faktor dari luar antara lain, (1) keadaan lingkungan sekitar, (2) pendekatan yang digunakan oleh orang tua dalam membimbing anak, dan (3) pembawaan dari orang tua.

\section{SIMPULAN}

Berdasarkan hasil penelitian dengan judul Analisis Perhatian Orang Tua Selama Pembelajaran Daring Terhadap Kemampuan Pemahaman Matematis Siswa, dapat diambil beberapa kesimpulan sebagai berikut.

1. Perhatian orang tua yang diberikan kepada siswa mendapatkan hasil bahwa sebagian besar orang tua memberikan perhatian kepada siswa. Perhatian yang diberikan kepada anak seperti, (1) memberikan bimbingan, berupa mendampingi anak saat belajar, membimbing ketika terdapat kesulitan, dan mengingatkan anak untuk belajar, (2) memberikan nasihat, berupa nasehat untuk mengutamakan kejujuran, nasehat pentingnya belajar dan tidak malas dalam belajar, (3) memberi motivasi dan penghargaan, berupa memberi reward, memberi pujian, dan memberi masukan, (4) memenuhi kebutuhan anak, seperti menyediakan ruang belajar, menyediakan perlengkapan sekolah dan fasilitas belajar anak, dan (5) pengawasan terhadap anak, seperti mengawasi anak saat belajar, mengatur jam belajar dan bermain, menanyakan masalah/kesulitan yang dihadapi.

2. Faktor-faktor yang dapat memengaruhi perhatian orang tua antara lain (1) adanya keinginan/kebutuhan, (2) kuat tidaknya stimulus, (3) kesibukan kegiatan/pekerjaan, (4) kondisi fisik, (5) suasana jiwa dan sekitar, dan (6) kemampuan pendidikan orang tua.

3. Siswa memiliki tingkat kemampuan pemahaman matematis yang cukup dengan jumlah 5 siswa yang tuntas dan 4 siswa yang tidak tuntas. Pada penelitian ini bukan hanya perhatian orang tua yang menjadi faktor dalam kemampuan pemahaman matematis siswa. Tetapi terdapat faktor yang lain yang mempengaruhi kemampuan pemahaman matematis siswa, faktor dari siswa itu sendiri dan faktor dari luar. Faktor dari dalam siswa antara lain, (1) tingkat kecerdasan yang dimiliki siswa, (2) minat dan motivasi siswa untuk belajar matematika, dan (3) konsentrasi siswa saat belajar. Sedangkan faktor dari luar antara lain, (1) keadaan 


\section{JURNAL ILMIAH}

BINA EDUKASI

ISSN 1979-8598 E-ISSN: 2655-8378

http://journal.binadarma.ac.id/index.php/jurnalbinaedukasi

Vol. 14, No. 1, Juni 2021, 01 - 10

lingkungan sekitar, (2) pendekatan yang digunakan oleh orang tua dalam membimbing anak, (3) pembawaan dari orang tua. 


\section{JURNAL ILMIAH}

BINA EDUKASI

ISSN 1979-8598 E-ISSN: 2655-8378

http://journal.binadarma.ac.id/index.php/jurnalbinaedukasi

Vol. 14, No. 1, Juni 2021, 01 - 10

\section{DAFTAR PUSTAKA}

Alan, U.F. dan Afriansyah. (2017). "Kemampuan Pemahaman Matematis Siswa Melalui Model Pembelajaran Auditory Intellectualy Repetition dan Problem Based Learning”. Jurnal Pendidikan Matematika. 11(1), 68-78.

Hamdani. 2011. Strategi Belajar Mengajar. Bandung: CV Pustaka Setia.

Kemdikbud. (2003). Undang-Undang Sistem Pendidikan Nasional Nomor 20 Tahun 2003. Jakarta: Kementerian Pendidikan dan Kebudayaan.

Koyimah, Eliyana. 2016. Hubungan Perhatian Orang Tua dengan Hasil Belajar IPS pada Siswa Kelas V SD N Gugus Ki Hajar Dewantara Kabupaten Semarang. Skripsi. Tidak diterbitkan. Fakultas Ilmu Pendidikan. Universitas Negeri Semarang: Semarang.

Martsiswati, E. dan Suryono. (2014). "Peran Orang Tua dan Pendidik dalam Menerapkan Perilaku Disiplin terhadap Anak Usia Dini”. Jurnal Pendidikan dan Pemberdayaan Masyarakat. 1(2), 187-198.

Oktoviani, V., Widoyani, W.L., Ferdiyanto, F. 2019. "Analisis Kemampuan Pemahaman Matematis Siswa SMP pada Materi Sistem Persamaan Linear Dua Variabel". Jurnal Edumatica. 9(1), 39-45.

Safitri, T., Sucipto, Henry S.B. (2018). Penerapan Model Jigsaw Berbantu Permainan Ultra 3D untuk Peningkatan Pemahaman Matematis. ANARGYA: Jurnal Ilmiah Pendidikan Matematika, 1(2), 110-121.

Satiadarma, Monty. 2001. Persepsi Orang Tua Membentuk Perilaku Anak: Dampak Pygmalion di dalam Keluarga. Jakarta: Pustaka Populer Obor.

Setyosari, Punaji. 2012. Metode Penelitian Pendidikan dan Pengembangan. Jakarta: Prenada Media Group.

Silahuddin. (2015). Penerapan E-LEARNING dalam Inovasi Pendidikan. Jurnal Imiah CIRCUIT, $1(1), 48-59$.

Sugiyono. 2014. Metode Penelitian Pendidikan (Pendekatan Kuantitatif, Kualitatif, dan R\&D). Bandung: Alfabeta.

Suryabrata, Sumadi. 2014. Psikologi Pendidikan. Yogyakarta: Rajawali Pers. 